\title{
On the Mechanism of Translocation in Plant Tissues. An Hypothesis, with special reference to Sugar Conduction in Sieve-tubes.
}

\author{
BY
}

\begin{abstract}
SYDNEY MANGHAM, M.A.,
Lecturer in Botany, Armstrong College, Newcastle-on-Tyne, in the University of Durham.
\end{abstract}

\section{With two Figures in the Text.}

$\mathrm{T}$ $\mathrm{HE}$ transference of products of metabolism from their sources to their destinations, as in the case of sugars formed in leaves and stored or consumed in subterranean organs, may involve journeys over considerable distances, especially in the case of large trees.

While it is highly improbable that any particular molecule, say, of dextrose ever passes immediately after formation rapidly over the whole path from leaf to root tip, yet movement for a certain distance obviously occurs.

Evidence has accumulated ${ }^{1}$ showing that, in the case of sugars, sievetubes play an important part in the normal process of translocation, and that Czapek's ${ }^{2}$ view that these elements provide the chief path for their rapid transference is the correct one.

It is, in practice, scarcely possible to deal with the path taken by assimilates during their passage from the photosynthetic system without reference to the physico-chemical processes involved.

The present paper is the outcome of attempts made to form some mental picture, in terms of physical chemistry, of what actually happens during certain phases of the process under consideration.

It is almost unnecessary to say that any active flow of material through plant tissues must be associated intimately with the properties of living protoplasm, and so with its structure.

Czapek ${ }^{3}$ carried out a number of experiments in which he subjected petioles to killing by heat and by chloroform, to plasmolysis, and to

1 Mangham (1910-11). An account of relevant anatomical and physiological data.

2 Czapek (1897).

3 Czapek, l.c., pp. I40-6o.

Annals of Botany, Vol. XXXI. No. CXXII. April, 1917.] 
narcosis, and noted the effect of the treatment on the removal of starch from the leaves. He found that killed elements no longer permitted translocation to go on, but that unkilled plasmolysed ( 5 per cent. $\mathrm{KNO}_{3}$ ) cells behaved almost as normal ones. Narcosis prevented translocation, which, however, recommenced on recovery of the cells.

Deleano ${ }^{1}$ criticized particular features of this work, but the conclusion drawn by Czapek that translocation is dependent upon protoplasmic activity remains unshaken.

In the paper referred to, Czapek appeared to consider that during translocation sugar is actively taken into the substance of the protoplasm, chemically combined with it, and then excreted again on the other side, where it is taken into the protoplasm of the next cell after diffusing through the intervening cell-wall. ${ }^{2}$ The vacuole was regarded as a sort of reservoir of nutriment for the protoplasm.

His views with regard to the rôle of connecting-threads are related to observations depending on a technique which has since been greatly improved upon.

It is interesting to note that $\mathrm{C}$ zapek found that translocation occurred in isolated plant portions, provided that a sufficient length $(\mathrm{e} . \mathrm{g} .12 \mathrm{~cm}$. in one experiment with Vitis) of conducting path remained in connexion with the leaf. ${ }^{3}$

Of recent years much work has been done aiming at elucidating the properties and finer structure of protoplasm. In particular, the outer bounding layer, of undefined thickness, generally known as the 'plasmatic membrane', has received attention at the hands of many investigators. ${ }^{4}$

The majority of these researches have been concerned closely with the determination of the permeability of this membrane to various solutes, with the relation of permeability to changes in external factors, with the antagonistic action of some salts upon others, and with the effects of anaesthetics. ${ }^{5}$

Many valuable results have been obtained, and light has been thrown upon the structure of protoplasm and of the membrane in question.

While at the present time the knowledge available is insufficient to permit, for example, of a satisfactory diagrammatic representation of the spatial distribution of the constituent particles of the membrane, yet it seems clear that the protoplasm as a whole forms a heterogeneous system, or colloidal complex, in which water, proteins, and lipoids are important components.

As stated by the Gibbs-Thomson rule, in such a system substances which in any way are able to lower the energy of the surface will, if free to

1 Deleano (1911). Cf. Schroeder (1911) for abstract and an estimate of the value of Deleano's conclusions.

${ }^{2}$ Czapek, 1.c., p. I58. 3 Ibid., pp. I48-9.

- Atkins (1916) and Bayliss (1915). General accounts and bibliographies are given. 
move, tend to accumulate at that surface, while those increasing surface energy will recede from the surface.

It is therefore probable that the protoplasm shows a more or less stratified structure, in accordance with the surface energy relations of the chemical compounds present. Lipoids, for example, owing to their great power of lowering surface tension, would tend to dispose themselves in the outermost layers of the protoplasm.

It is important to bear in mind that in such a complex colloidal system as is here contemplated, since the surface of the components is highly developed, adsorption phenomena will occur to a very large extent.

Substances in solution inside the vacuole may therefore become concentrated at every surface of separation between two different phases, in such a way as to secure the maximum lowering of the energy of the system as a whole.

The protoplasm may then be pictured not merely as a combination of a suspension of particles and an emulsion of droplets in an aqueous medium, with probably also other components in the form of gels, but in addition account must be taken of the fact that in the watery phase various solutes are present, and furthermore that they may exist there in a concentration differing from that obtaining at the actual surface of separation of the water from the other phases.

It is well known that a reversible equilibrium exists between the concentration of a solute in its solvent and at the surface of an adsorbing substance introduced into the solution.

To take an example, ${ }^{1}$ if equal amounts of charcoal are shaken up with dilute acetic acid in known concentrations, a certain proportion of the acid is removed from each solution owing to local concentration,-or adsorption, at the surface of the charcoal particles.

Quantitative estimations have shown that from the weaker solutions a relatively larger proportion is removed than from the stronger ones. This relation can be expressed by a curve of the type shown in Fig. I.

Put in another way, if to a very fine suspension of charcoal in water acetic acid is added, and the mixture well shaken, the acid will distribute itself throughout the system in a definite manner such that the concentration at the surface of the charcoal bears a specific relation to that of the acid remaining in solution.

If more acid is then added, a new state of equilibrium will be obtained, the concentration of acid becoming increased at the charcoal surface, but relatively more increased in the solution.

Similarly, if more water is added to the original solution, the concentration of the acid at the surface of the charcoal will become decreased, but that of the acid in solution will become relatively more decreased.

\footnotetext{
1 Philip (1913), pp. 227-30 and p. $23^{2}$.
} 
It is clear then, that if changes occur in the concentration of solutes present in a heterogeneous system containing one or more constituents capable of adsorbing them, there will be a succession of readjustments of equilibrium between the concentration of the solute at the surface of the adsorbing phase and that of the solute in the solvent.

Such changes may be brought about in plant cells owing to variations in the supply of both water and of solutes. Thus there would result a state of continuous flux, the solute constantly varying in concentration in the two regions.

It should be realized that the conception here outlined does not imply

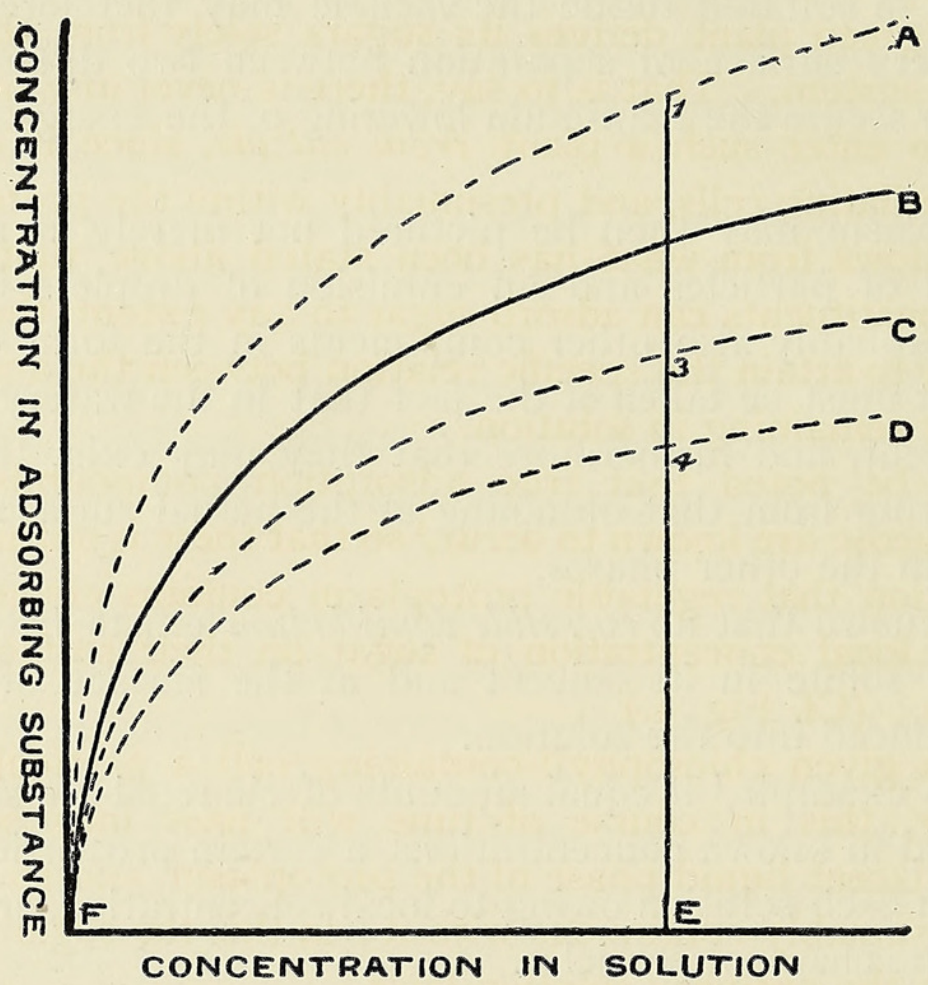

Fig. I. FB, Type of curve showing reversible adsorption equilibria with a given solute, solvent, and adsorbing phase B. The broken lines represent equilibria with other adsorbing phases A, C, and D, in which the solute is assumed to undergo different degrees of adsorption indicated by $\mathrm{E}_{\mathrm{I}}, \mathrm{E} 3$, and $\mathrm{E}_{4}$.

that particular molecules of sugar are, as it were, fixed on the surface of the adsorbing phase, while others are free to move in the solvent, but rather that molecules are at all times passing from the surface of the adsorbing phase into the body of the solvent, and vice versa, in such a manner that a definite relation between their concentrations in the two regions is maintained while the conditions are constant.

There is therefore the possibility that an individual molecule might remain for a very long period in, say, a bundle-sheath cell, if it managed to confine its peregrinations to the more central parts of the vacuole well out of immediate reach of the protoplasm. Obviously the layer of solution actually bathing the adsorbing substance will be the site of initial re- 
adjustments when equilibrium is disturbed; it will take time for the effect produced in this peripheral portion of the vacuole to be transmitted (by diffusion of solute) throughout the whole of the cell sap.

Emphasis must be laid upon the enormous area of the protoplasmic linings of plant cells compared with the volume of the tissue which they compose, for in this way innumerable small reservoirs are provided, and these are readily accessible to the protoplasm. There is therefore available very extensive machinery by means of which translocation can be effected in the manner to be described.

It is now proposed to apply these considerations to the case of sugar transport within the plant.

A normal green plant derives its sugars solely from the cells of the photosynthetic system. That is to say, there is never any question of the sugar having to enter such a plant from outside, since it actually arises within the assimilating cells, and presumably within the protoplasm itself.

Now it follows from what has been stated above, that if any of the protoplasmic constituents can adsorb sugar to any extent, there will always exist a tendency to attain the specific relation between the amount adsorbed and the amount remaining in solution.

It should be noted that true adsorption compounds of albumen, lecithin, and glucose are known to occur, ${ }^{1}$ so that there is nothing improbable in the supposition that vegetable protoplasm contains elements capable of bringing about local concentration of sugar on their surfaces, possibly in varying degrees. (Cf. Fig, I.)

When in a given chlorophyll-containing cell a particular plastid has produced sugar, this in course of time will pass into solution in the immediately adjacent liquid phase of the protoplasm, and so into the sap of the vacuole presumably continuous with it; in this the sugar will diffuse in accordance with the ordinary solution laws.

Since, however, particles capable of adsorbing sugar are assumed to be distributed throughout the protoplasm, the sugar will tend to accumulate at their surfaces.

Consequently, the two processes of diffusion through the solvent, and adsorption at the surface of protoplasmic components, would contribute to the transference of the sugar.

If the adsorbing particles were few and relatively distant one from another the ultimate rate of movement of the sugar would be conditioned almost entirely by the rate of diffusion in the continuous liquid phase, that is, it would probably be extremely slow.

If, however, the adsorbing particles were fairly numerous and comparatively close together, the diffusing sugar molecules would not have far to travel before reaching the surface of one of them.

$$
1 \text { Bayliss, 1.c., pp. } 57 \text { and 66. Cf. also p. } 65 \text {. }
$$


Finally, if the adsorbing material were present either in very high concentration, so that the particles were only separated from one another by an infinitesimally thin film of solvent, or were actually continuous, forming a meshwork, as is probably the case in a gel, the distance to be traversed before coming into contact with a surface in which concentration could occur would be reduced still more.

The rate of transference would then approximate to that at which condensation on the surface of the adsorbing phase would occur, that is, in all probability it would be extremely rapid. ${ }^{1}$

The specific concentration relations existing between the particular substances concerned at the adsorbing surface and in the layer of solvent immediately in contact with it would, of course, obtain, so that there would be a wave of adjustment to a state of equilibrium, the rate of propagation of which would depend on the rate of spreading of the sugar over the adsorbing materials.

So far, the process has been dealt with only partially, and has been treated as if the sugar formed in the photosynthetic cells passed onwards into protoplasm and solvent containing no sugar. This is simply for purposes of description, and is hardly likely to represent a state of affairs ever occurring in the plant.

Actually the process must be more complex, although conditioned by the principles enunciated above.

It is possible now to pursue the matter somewhat farther.

In the case of a single cell, such as a unicellular green alga, the sugar would diffuse into the vacuole, and the concentration there and at the surface of the protoplasmic constituents would tend to reach a state of equilibrium, which, however, would be continually disturbed by the metabolic changes incidental to growth and reproduction.

In a filament such as Spirogyra the conditions would probably be much the same, since the plant is simply a series of equivalent cells all under practically identical conditions.

With such a plant as Laminaria, however, the existence of tissue differentiation and of localized meristematic regions adds complications. Here the carbohydrates are produced in those of the outer cell layers into which light penetrates. The inner layers, being shaded, assume other functions.

The soluble assimilates would travel as above described in the cells producing them. But the protoplasm of each cell is continuous with that of its neighbour by means of the connecting-threads in the walls. ${ }^{2}$

The solutes have an unbroken protoplasmatic pathway throughout the

1 Cf. Bayliss, 1.c., pp. $5^{6}$ and 6r.

2 Sykes (1908). It is here assumed that a real continuity of protoplasm exists, although the exact nature of ' median nodules' has not been ascertained. 
plant, although in most tissues considerable restrictions are placed on speedy transference in quantity from cell to cell owing to the extreme tenuity and comparatively small number of the threads, which oppose rapid motion in much the same way as turnstiles at a barrier limit the rate of passing of a crowd of people from one side to the other.

Similar considerations would apply to the case of a normal green foliage leaf. The sugar formed in the mesophyll would be able to pass from cell to cell by way of the connecting-threads, and so would reach the protoplasm of the bundle-sheath cells near the endings of the fine veins. Its farther path will be dealt with later on.

At all regions in the plant where meristematic tissue occurs, and especially at the cambium, and at the apices of roots and shoots, or where storage is going on, as well as throughout the whole of the living tissues which are continually undergoing respiration, great consumption of soluble carbohydrates occurs. This means that in such cells the concentration of these substances is continually varying.

To form starch reserves, or new cell walls, or to produce fibres or 'stone-cells', sugar must be withdrawn and its concentration become lowered temporarily at the place of withdrawal.

Any such lowering of concentration at one point of the protoplasm will affect the state of equilibrium which should obtain, as described above.

For example, if the sugar concentration is lowered at the surface of a particular protoplasmic particle, then more will pass from the immediately adjacent solution to become concentrated at the surface of this particle in order to re-establish the specific relation.

The solution will accordingly become locally weaker, and this will disturb the equilibrium between it and other particles in the vicinity; the latter will therefore give up a portion of their adsorbed solute, diffusion in the solvent will occur, and its effects be transmitted.

If carbohydrate consumption is vigorous, or long continued, its influence will be far-reaching.

Thus a wave of disturbance and readjustment of equilibrium is propagated, in much the same way as the firing of shells from a battery leads to the depletion of the immediate supply, followed by a replenishing from the reserves, \&c., and ultimately from the factory, so that the scheduled relations are maintained between the various stores at intermediate points.

Waves of this type will be sent out from all points where sugar is being transformed, and they will spread in all directions subject to structural limitations.

To a certain extent the cell vacuoles may be compared to a series of small water-tanks from each of which supplies may be drawn off by several pipes, and to which the losses may be made good by small-bored pipes connecting the bases of adjacent tanks. The small tanks must be imagined 
to be horizontally disposed and connected ultimately with a main supply pipe capable of delivering considerable quantities of water fairly rapidly.

Thus, if a tap is opened at one of the tanks water will flow out, and this will cause a flow from the adjacent tanks and from the others in turn, and finally water will pass in from the main. When outflow taps are opened at several tanks at once the level of the water in the individual tanks at any moment will depend upon the relations obtaining between rates of loss and supply for each one and the rate of delivery from the main.

In the plant the parenchymatous cells with their vacuoles correspond to the small tanks, the sieve-tubes represent the main supply pipe, while the connecting-threads take the place of the small-bored pipes.

It is desirable to consider the structure of the sieve-tubes in relation to the function here assigned to them.

In the finest veins of the leaves the phloem becomes reduced to a single sieve-tube with companion-cells in connexion with its segments, ${ }^{1}$ and finally the sieve-tube mother-cell, by failing to divide, gives rise to 'transition-cells', which are very much like enlarged companion-cells. ${ }^{2}$

The transition-cells are in longitudinal connexion with the sieve-tubes, while laterally they are contiguous with the cells of the bundle-sheath, as also are the companion-cells.

Soluble assimilates from the photosynthetic system must pass into the bundle-sheath. It is highly probable that they then pass into the transitioncells, which, being richly provided with protoplasm, would seem eminently fitted to exert considerable adsorptive suction, so to speak. ${ }^{3}$

In an ordinary leaf vast numbers of bundle-endings occur, so that each need only receive assimilates from a comparatively small number of photosynthetic cells.

Since the transition-cells are in direct continuity with the sieve-tubes, the assimilates could next pass into the latter.

So far, the distance traversed has been very small, equal in fact to the united lengths of a few mesophyll cells. The path over which movement has occurred in the manner described has included only a very few sets of protoplasmic connecting-threads.

Once the assimilates have entered the protoplasm of the sieve-tubes, however, they have a long continuous course practically free from obstacles, as will be seen from the following considerations of structure.

A sieve-tube usually has a very thin ${ }^{4}$ wall, and is lined with protoplasm. As shown more especially by the researches of Hill, ${ }^{5}$ the mature sieve-

1 Strasburger (1891). A number of figures are given.

2 Haberlandt (1914), p. 367, Figs. I 47 A, I47 B. (Reproduced in Mangham (1910-11), Figs. 9, I0.)

3 Vide infra, p. 305. Cf. Fig. I.

- Comparatively thick walls are to be found in many cases. Cf. Compton (1909).

s Hill $(1901,1908)$. 
plates, where investigated, have numerous fine perforations each lined with a protoplasmic tubule through which the fluid contents of adjacent segments are continuous.

Practically the whole area of the plate may be perforated in this way, so that a number of the minute channels occur quite close up against the lateral walls of the tube.

Above the level of the plate the facilities for wave propagation are proportional to the cross-sectional area of that part of the protoplasmic lining containing the sugar-adsorbing constituents. (Cf. Fig. 2.)

By a little consideration of Fig. 2 it readily appears that, owing to the existence of a number of perforations close to the periphery of the plate, the cross-sectional area of the protoplasmic sheath, which is continuous though

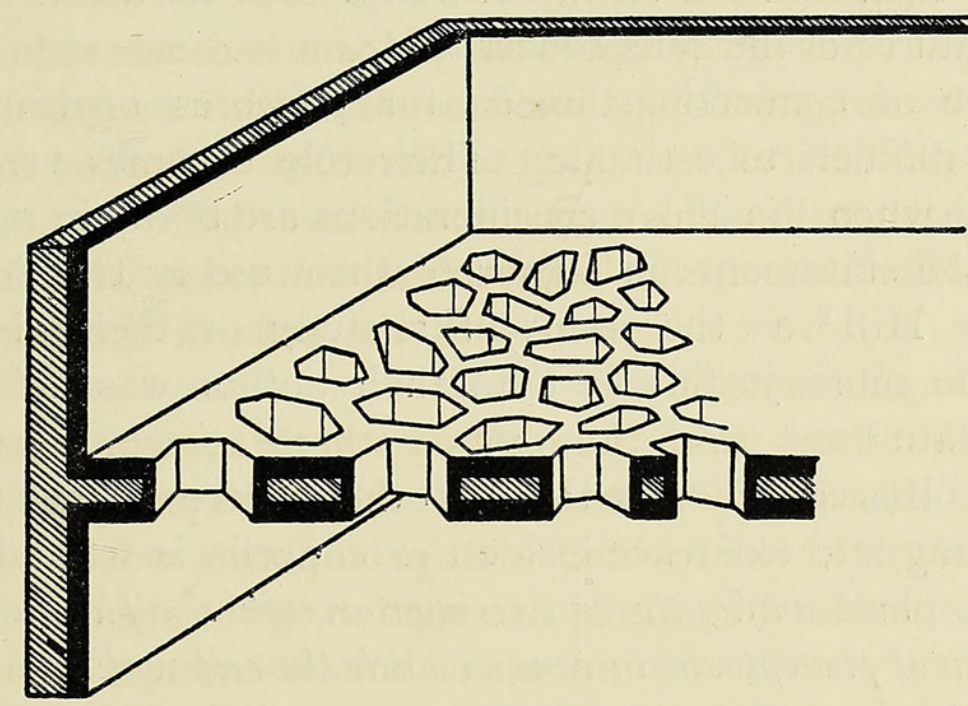

FIG. 2. Very diagrammatic representation of a portion of a sieve-plate and the walls of a sievetube to show continuity of protoplasm. Callose is omitted. Cell-wall, shaded. Protoplasm, white (surface), black (in section).

distorted, suffers little, if any, reduction at the level of the plate. At the most it is only as if the tube were provided with a narrow, inwardlyprojecting ledge, comparable, save for its irregularity, with an annular thickening of a vessel. ${ }^{1}$

As far then as its effect upon the propagation of a wave of restoration of concentration equilibrium is concerned, the existence of the more central portion of the plate may be almost neglected. It allows the free passage of various albuminous substances, \&c., so that the sieve-plate may be regarded as a very satisfactory structural compromise permitting of the two processes referred to, and at the same time retaining sufficient mechanical strength to guard against the collapse of the sieve-tube through pressure exerted by surrounding cells.

Fluctuations in concentration constantly occur throughout the living tissues, especially during periods of vigorous growth and storage.

1 The sieve-plate should be contrasted with a transverse wall having a single central perforation. 
Such disturbances of the equilibrium at any one region will start waves of readjustment, which will be communicated to the sieve-tubes in very much the same way as the turning on of a tap in a dwelling-house causes a flow of water in the main outside.

Owing to their special structure the waves could be propagated much more effectively in the sieve-tubes, which are continuous from leaf to root, than in any other type of plant cell, with the exception of laticiferous elements, to which similar considerations might be applied.

The sieve-tubes are richly provided with connecting-threads on their lateral walls adjoining the companion-cells, and the walls of the latter are freely connected with the phloem parenchyma cells and with the medullary rays. ${ }^{1}$

It is clear then that the views here expressed harmonize well with the histological features of the cells concerned.

The value of conrecting-threads for purposes of translocation has hitherto been difficult to estimate. Their rôle becomes very much more comprehensible when the above considerations are borne in mind, and it can be seen that the statements in favour of their use in translocation, which were made by $\mathrm{Hill}^{2}$ as the result of a study of their distribution and frequency, were more justifiable than their author was led to believe at a subsequent date. ${ }^{3}$

It will be observed that on the hypothesis here formulated the sugar originally coming into existence inside the leaf cells is treated as travelling throughout the plant without ever passing through the plasmatic membrane, or outer surface of protoplasm in contact with the cell-wall.

That this layer of the protoplasm in rnost plants is only with difficulty penetrated by sugars from outside (thus allowing sugar solutions to be used to effect plasmolysis) has been repeatedly shown. ${ }^{4}$

It is interesting to note that Ruhland ${ }^{5}$ found the protoplasm of sievetubes to be no more permeable to sugars than the protoplasm of other cells.

Another well-known property of protoplasm is its power to prevent the escape of sugar from inside most cells, as in the case of root-hairs, Algae, \&c., when placed in water. ${ }^{6}$

It is rather a point in favour of this hypothesis of translocatory mechanism that it does not require alternating passages of the sugar in and out of the protoplasm of adjacent cells through the plasmatic membrane and across the intervening cell-wall.

In this connexion fibres and the 'stone-cells' of fruits are instructive. The walls of these elements often attain considerable thickness, and require

1 Hill (1908).

2 Ibid. (1901).

3 Ibid. (1908).

4 Yeast-cells, saprophytic mycelia, \&c., are permeable to sugars.

5 Ruhland (1911).

6 Cf. also sugar retention by blood. It has been suggested that the sugar is held in combination with the proteins of the blood except under pathological conditions, e. g. in diabetes. Cf. Beddard (1905), Pp. jo8-I I. 
comparatively large amounts of sugar for their formation. These walls are provided with numerous deep pits, through the closing membrane of which the protoplasm is continuous by means of connecting-threads while the cell is alive. The cells of the date 'stone', which furnish a reserve of carbohydrate for the use of the seedling, are especially favourable for observing similar features.

It is surely much more reasonable to suppose that the sugar needed for the construction of these walls passes in by way of the connecting-threads in the manner above described, than to assume that it passes from cell to cell repeatedly through wall substance of ever-increasing thickness.

In such extreme cases the former supposition seems fairly obvious, but it is here contended that sugar exchange is effected in the same way in cells with walls of ordinary thickness.

It should be borne in mind that the length of connecting-threads is in all cases determined by the thickness of the pit-closing membrane, and that the significance of the thin walls of parenchymatous cells is probably to be found in their extensibility, \&c., in connexion with osmotic phenomena and the maintenance of turgor, rather than in any special facilities they may provide for permeation by metabolites. ${ }^{1}$

As mentioned above Czapek stated that plasmolysis of a portion of a petiole did not prevent the removal of assimilates from the leaf.

Deleano ${ }^{2}$ considered that the procedure adopted by Czapek gave no guarantee that the more central parts of the petiole became plasmolysed, and he concluded that translocation through plasmolysed cells was not possible. In his own experiments, however, he does not appear to have made certain that the cells were not killed by the plasmolysing solution.

It may be remarked that even when fairly strongly plasmolysed the linings of consecutive sieve-tube segments would be much less liable to become severed than would those of any of the other cells present. In spirit material, for example, the protoplasmic lining is usually contracted about the middle region of each of the segments, but is continuous through the sieve-plates.

If translocation is effected in the manner here suggested, it is hardly likely that plasmolysis (short of killing) would interfere with the efficiency of the sieve-tubes, since the continuity of their protoplasm would probably remain unbroken between the normal portions of petiole above and below the part plasmolysed.

An interesting histological feature which lends support to these views is

1 In specialized absorptive organs, however, thin walls obviously facilitate the entry of substances from outside, e.g. from the soil solution in the case of root-hairs. Gaseous exchange, too, is similarly aided.

${ }^{2}$ Deleano, 1.c. Czapek, however, apparently satisfied himself on this point (1. c., p. 146), and also made sure that the tissues recovered their turgor when the plasmolysing solution was replaced by water. 
to be found in the case of the relations of the sieve-tubes of Cuscuta to those of the host plant.

Details have been investigated more especially by Peirce ${ }^{1}$ and by Thoday (Sykes). ${ }^{2}$ The latter found that after the haustorial cells of the parasite had penetrated into the vascular tissue of the host, a very close union was effected by some of them with the sieve-tubes. By absorption of the end walls the protoplasm of these haustorial cells eventually came into actual contact with sieve-fields or sieve-plates.

As the haustorial cells so united themselves take on the structure of sieve-tubes, and are in connexion with the phloem of the parasite, there results a continuity of sieve-tube protoplasm between the two plants.

Here it may be stated that experimental investigation by means of the osazone method for locating sugars in plant tissues ${ }^{3}$ has shown that the sieve-tubes of the host, and the haustorial elements united with them, may both contain greater amounts of sugar than occur in the other tissues.

These results, details of which will, it is hoped, be incorporated in a later paper, go some way towards confirming the correctness of the view here taken as to the rôle of sieve-tubes in sugar conduction, and help to emphasize the importance of protoplasmic continuity for effecting translocation.

Albuminous compounds present in the contents of the sieve-tubes may serve to increase the adsorptive capacity of these cells, and thus may add to their power of accumulating sugar. (Cf. Fig. I.)

The advantage to the plant of close association in a common path of such important metabolites as carbohydrates and nitrogenous organic bodies scarcely calls for comment.

The continuity of protoplasm which occurs in graft hybrids ${ }^{4}$ might also be interpreted on lines similar to those taken in the case of Cuscuta and its host.

Another point calling for some consideration is that the protoplasm itself can scarcely be exactly the same in constitution and properties throughout the plant. ${ }^{5}$

The very existence of cell differentiation indicates that the protoplasm of a cell of one type differs in some respect from that of another.

The exact nature of these protoplasmic differences can only be surmised, but their results are often easy to observe. In many cases they

1 Peirce (1893). Cf. Pl. XIII, Fig. 7 , and Pl. XIV, Figs. 14,17 , and 18.

2 Thoday (Sykes) (1911). It is fair to state that in this paper no claim is made to the effect that absolute continuity of protoplasm is established (cf. pp. 671, 672). The association is, however, extremely close:

3 Mangham (1915). 4 Hume (1913).

5 Striking examples of differentiation are to be found in the case of the sporangiophore of Pilobolus, which actively excretes water, and in the case of nectaries, from which sugary liquids exude. 
are expressed by specific chemical activities. Cell-walls may become thickened, either permanently or for the purpose of temporary storage. Production of aromatic compounds may occur in certain types of cells, or a glucoside may be stored for a time in one region, while the enzyme compatible with it is confined to another.

There is also the possibility of change with senescence.

Benedict ${ }^{1}$ studied the leaves of various deciduous plants and concluded that the observed facts could best be accounted for by assuming that among other changes a decrease in the permeability of the protoplasm (to water and salts) occurred with advancing age.

Again, the inability of many unicellular organisms to continue purely vegetative reproduction indefinitely has led to the suggestion that sexual fusion in some way rejuvenates the protoplasm.

It would not therefore be surprising to find that certain protoplasts could effect a greater adsorption of sugar than others, so that a higher concentration would be reached in their vacuoles before the protoplasm became adsorptively saturated. (Cf. Fig. I.)

In such cells sugar would tend to accumulate more than in other cells, and in this manner a directive influence could be exerted upon sugar transference. For example, if the protoplasm lining the sieve-tube segments in the leaf became adsorptively saturated with a lower concentration of sugar than that needed to produce this result in the petiole and stem sievetube segments, then sugar would tend to become concentrated more in the latter segments and to be withdrawn from the leaf.

Such gradients in sugar concentration in sieve-tubes have actually been found to occur, in the case of leaves allowed to remain in darkness for a day or two before being examined for sugar distribution by the osazone method. ${ }^{2}$

The views here set forth are in harmony with what was previously known with regard to the flow of sugar in the plant.

Experiments made by Schimper, ${ }^{3}$ for example, showed that during darkness sugar disappeared from leaves, and travelled from regions of low to regions of higher concentration, i. e. apparently against the ordinary laws of diffusion.

It is difficult to account for this on lines other than those indicated above. An hypothesis which involves the outward passage of sugar through the plasmatic membrane of one cell followed by the penetration of the membrane of the next protoplast appears to be more arbitrary and less comprehensible than that suggested here.

The present hypothesis enables one to understand how the varying and widespread demands made by the plant upon its sugar supplies are met, viz. by the propagation of waves of readjustment of concentration

1 Benedict (1915).

2 Mangham (1910, 1910-11, 1911 (1), 1915).

3 Schimper (1885). 
equilibrium, waves which travel through the protoplasm by way of the connecting-threads, and finally reach the sieve-tubes, which act in part as sugar reservoirs, and in which such readjustments can be made more effectively than in other cells.

The sugar requirements of the cambium cylinders, \&c., throughout the plant will result in lateral withdrawal from the sieve-tubes and from such storage tissues as phloem parenchyma and medullary rays.

In this process, as well as in the reverse one of storage, the companioncells probably play the part of intermediaries.

These cells do not, as a rule, form longitudinally connected series, but are frequently disposed somewhere between the sieve-tubes and the cells of the bundle-sheath in leaves, while in the stem they often occur between the sieve-tubes and the phloem parenchyma or the medullary ray tissue.

It was shown by Gardiner and $\mathrm{Hill}^{1}$ that the distribution of connectingthreads in the leaf of Pinus was such as to suggest that food material could most readily travel to the sieve-tubes by way of the albuminous cells, and Hill $^{2}$ demonstrated that the latter, in the stem, were very well connected with the medullary ray parenchyma.

As already mentioned, the companion-cells of the Angiosperms studied in this way were found to have numerous protoplasmic connexions with the sieve-tubes on the one hand, and with the phloem parenchyma on the other.

The albuminous cells of the Gymnosperms are probably physiologically comparable with the companion-cells of the Angiosperms, and it would seem that the rôle in each case is to act as agents between the sieve-tubes and adjacent tissues during the lateral exchange of assimilates. With the present hypothesis the comparatively great development of connectingthreads in the walls of the companion-cells receives a rational interpretation.

Experimental demonstration of this function of the cells under consideration is difficult, for at least two reasons.

In the first place, owing to their small cross-section, and to the absence of longitudinal continuity, the companion-cells do not lend themselves readily to observation, as a little experience shows.

In the second place, it is obvious that translocation might go on effectively by the rapid movement of sugar present in concentrations too low to permit of satisfactory detection by the microchemical methods available.

It is, however, proposed to reserve further consideration of these and kindred points until opportunities permit of describing in some detail results obtained by the use of the osazone method of locating sugars in plant tissues.

The foregoing considerations may be applied to all plants. ${ }^{3}$

For example, the sieve-tubes ${ }^{4}$ of the larger Brown Algae, plants which

1 Gardiner and Hill (1901).

2 Hill (1901).

3 Saprophytes need further treatment beyond the scope of the present paper.

4 Oliver (1887) and Sykes (1908). 
have localized meristems and grow fairly rapidly, are histologically remarkably similar to those of Angiosperms, and must provide the same facilities for translocation. Some confirmatory experimental evidence in support of this contention has been obtained by the osazone method, ${ }^{1}$ but the work is not yet complete.

In such plants as Mosses, which are never very large, and modern Lycopodiales, which are microphyllous with closely arranged leaves, and grow comparatively slowly, demands for vigorous sugar transport are less urgent than in the higher plants; this is correlated with a less advanced development of special conducting cells.

True sieve-tubes have not been demonstrated in the Mosses, but in the larger types there are elements called 'leptoids' ${ }^{2}$ which have been assumed to provide conducting channels for assimilates.

Histological examination ${ }^{3}$ of the vegetative portions of Polytrichum has revealed the fact that the connecting-threads in the leptoids are very numerous indeed, though they show no sign either of being bored out to give slime-strings, or of being enclosed in tubules of callose.

In the terminal walls of the leptoids the connecting-threads are far more numerous than in any other type of cell in the plant. These walls are often very oblique and usually bag-shaped, the end of a cell often giving the effect of being slightly invaginated. In this way the area of the wall is even more increased than it would be if it were simply an obliquely placed plane.

While decisive evidence in support of the view that leptoids conduct assimilates has not been adduced, yet in the light of the considerations above it is clear that their histological features render them very suitable for such a function. The end walls are structurally of a type between the walls of ordinary parenchyma and true sieve-plates, and evidently suffice to meet requirements.

In the modern Lycopodiales the leaf leptome is of a simple type. In most cases numerous sieve-tubes occur in the stem, but they are not provided with companion-cells like those of the Angiosperms.

On the other hand, almost perfectly preserved examples of the fossil representatives of the group have been described as showing no elements which could appropriately be called sieve-tubes, ${ }^{4}$ and hence are devoid of secondary phloem, although the xylem underwent considerable secondary increase.

In this connexion the following considerations may be of interest.

1 Mangham (1911 (2)).

2 Tansley and Chick (1901).

s Hume (1913). In correspondence also Miss Hume has kindly supplied certain details of her work on Polytrichum.

* Seward (1902). In a recent letter Professor Seward has stated that he has no reason for changing the opinions expressed in the paper referred to. 
In the palaeozoic Lycopodiales, as in the modern Lycopodium, a very characteristic feature is to be found in the numerous closely arranged leaves, the bases of which in many cases practically cover the stem.

Each leaf is a factory for carbohydrates, \&c., so that as long as the leaves remain attached and functional, supplies of metabolites are passed into the stem radially at a very great number of places ; indeed, practically over the whole surface.

Such an arrangement contrasts very strongly with that to be found, for example, in Cucurbita, where a comparatively small number of large leaves are connected with a slender stem having long internodes.

In Lycopdium there is usually a fairly well-developed cortex, but the cortical tissue and the contiguous leaf bases of Lepidodendron comprise a relatively very much greater amount of parenchyma.

The stele of the modern Lycopods deviates as a rule more or less from the simple protostelic type, and in cross-section exhibits patches, bands, \&c., of phloem arranged between areas of xylem, an appearance differing considerably from that presented by transverse sections of Lepidodendron, where the xylem has a more or less regular circular outline.

Naturally, no information about the connecting-threads of Lepidodendron is available, but there is no reason for supposing that they differed in any important respect from those of living plants.

It is here suggested that in these fossil types there were not present those conditions requiring the production of elements specially equipped to enable rapid transport of metabolites to go on.

If we may judge by the modern Lycopodiales, the ancient types did not grow at all rapidly.

Their numerous leaves must have emptied their stores into the cortical cells near their junction with the stem, so that along the whole length of the leafy stem supplies were constantly being furnished from factories very close at hand.

The cortex might be regarded as a large reservoir which kept pace with the needs of the plant by increasing in extent.

It is clear then that in the stem, at any rate while the leaves persisted, very little need for longitudinal translocation existed.

With regard to the root system it may be suggested that the presence of a very large cortical zone continuous with that of the stem probably afforded a sufficient cross-sectional area to permit of adequate translocation through ordinary connecting-threads.

In the modern Lycopods there appears to have been a reduction in cortical tissues, and a more or less complementary development of specialized food-conducting cells.

It is as if, in the course of their evolution, the Lycopodiales, like other plant groups, had hit upon the idea of the sieve-tube, and so had discarded 
the cumbersome and uneconomical method of providing for translocation which had existed in Lepidodendron and its contemporaries.

On the hypothesis of translocatory mechanism here put forward it can be seen that in Lepidodendron there was little, if any, physiological necessity for the development of cells comparable with the sieve-tubes of more recent plants.

\section{SUMMARY.}

The paper is the outcome of an attempt to form a mental picture, in terms of physical chemistry, of what goes on in the plant cell during certain phases of sugar translocation.

The work of recent years tends to show that protoplasm contains proteins and lipoids among other substances, and that these form with water a complex colloidal system.

It is probable that one or more constituents are present as gels.

In so far as the component substances are free to move they must be disposed in accordance with their power of lowering the energy of the system ; protoplasm may therefore exhibit stratification.

Definite relations have been found to obtain between the concentration of a solute at the surface of adsorbing particles introduced into the solution and the concentration of the solute in the solvent. This state of equilibrium is reversible.

The case of charcoal and acetic acid is cited.

Adsorption compounds of albumen, lecithin, and glucose are known.

It is suggested that in vegetable protoplasm there are present constituents capable of adsorbing sugars from solution.

For any given concentration of sugar present in the liquid phase of the protoplasm, and the cell sap continuous with it, there would be a definite concentration of sugar present at the adsorbing surface.

Any alteration of concentration in either region would lead to a readjustment of concentration equilibrium, which would be propagated as a wave through the system composed of the adsorbing particles and the solution immediately in contact with them.

The rate of propagation of this wave would depend very much upon the degree of approximation of the particles under consideration, and would increase as the distance between them decreased.

Connecting-threads are assumed to provide a continuous protoplasmic pathway, though they impose restrictions varying with their frequency and tenuity.

The structure of the sieve-tube is considered, and it is shown that the sieve-plate would cause little, if any, obstruction to the progress of the wave of readjustment of concentration equilibrium, so that the sieve-tube would 
permit the passage of the waves with more effect than would be possible in any other type of cell, except laticiferous elements.

The relations of the haustorial cells of Cuscuta to the sieve-tubes of the host plant, and especially the fact that almost complete, if not absolute, continuity of protoplasm is established between the sieve-tubes of the two plants, are interpreted as supporting the views advanced, as also are certain results obtained by the osazone method of locating sugars.

It is suggested that in Angiosperms the 'transition-cells' at the bundleendings in leaves, and the companion-cells elsewhere, act as intermediaries in the exchange of sugar between the sieve-tubes and adjacent tissues.

In the Gymnosperms the albuminous cells probably have a similar function.

In a normal green plant sugar is synthesized inside the photosynthetic cells, and is not taken in as such from outside.

The hypothesis does not require the passage of sugar outwards through the plasmatic membrane of one cell and inwards through the membrane of the next cell; it thus falls into line with the known small permeability of protoplasm to sugars present outside, and with the power of protoplasm to retain sugars occurring inside the cells.

The structural features of fibres, stone-cells, and the endosperm of Phoenix are interpreted as furnishing further evidence in support of the hypothesis.

Differences in the adsorptive properties of the protoplasm in various parts of the plant, together with changes incidental to senescence, may also share in exerting a directive influence upon translocation.

Reference is made to the application of the hypothesis to various plant groups, in particular the larger Brown Algae, the Mosses, and the Lycopodiales.

\section{LITERATURE CITED.}

Atkins, W. R. G. (1916): Some Recent Researches in Plant Physiology. Whitaker.

BAyliss, W. M. (1915): General Physiology. Longmans.

Beddard, A. P. (1905) : Recent Advances in Physiology and Biochemistry. (Edited by L. Hill.) Arnold.

Benedict, H. M. (1915): Senile Changes in Leaves of Vitis vulpina and certain other Plants. Cornell Univ. Agric. Expt. Sta., Mem. No. 7. Abstract by Child in Bot. Gaz., vol. lxi, I916, pp. 435-8.

Blackman, F. F. (1912): The Plasmatic Membrane and its Organization. New Phyt., vol. xi, p. 180 .

Compton, R. H. (1909): The Anatomy of Matonia sarmentosa. New Phyt.

CzAPEK, F. (1897 (1)): Über die Leitungswege der organischen Baustoffe im Pflanzenkörper. Sitzber. d. k. Akad. d. Wiss. in Wien, vol. cvi, pp. I I $7-70$.

(1897 (2)): Zur Physiologie des Leptoms der Angiospermen. Berichte d. deutsch. bot. Gesellsch., pp. I24-31. Cf. also Bot. Centralbl., vol. 1xxii, pp. 74-5. 
Deleano, N. T. (1911): Über die Ableitung der Assimilate durch die intakten, die chloroformierten und die plasmolysierten Blattstiele der Laubblätter. Jahrb. f. wiss. Bot., vol. xlix, pp. I 29-89.

Gardiner, W., and Hill, A. W. (1901): The Histology of the Cell-wall. Part I. The Distribution and Character of the Connecting-threads in the Tissues of Pinus sylvestris and other Allied Species. Phil. Trans. Roy. Soc., B, vol. cxciv.

Haberlandt, G. (1914): Physiological Plant Anatomy. (English translation by M. Drummond.) Hill, A. W. (1901) : The Histology of the Sieve-tubes of Pinus. Ann. of Bot., vol. xv.

(1908): The Histology of the Sieve-tubes of Angiosperms. Ann. of Bot., vol. xxii.

Hume, E. M. (1913 (1)) : On the Presence of Connecting-threads in Graft Hybrids. New Phyt., vol. xii, pp. 216-2I.

(1913 (2)): Histology of the Leptoids in Polytrichum. Rep. Brit. Ass., Birmingham, p. 708.

Mangham, S. (1910): The Paths of Translocation of Sugars from Green Leaves. Rep. Brit. Ass., Sheffield.

(1910-11): The Translocation of Carbohydrates in Plants. Science Progress, vol. v, pp. $256-85,457-79$.

(1911 (1)): On the Detection of Maltose in the Tissues of certain Angiosperms. New Phyt., vol. $x$, pp. 160-6.

(1911 (2)) : On the Presence of Sugar in the Tissues of Laminaria. Rep. Brit. Ass., Portsmouth.

(1915): Observations on the Osazone Method of locating Sugars in Plant Tissues. Ann. of Bot., vol. xxix, pp. 369-9I.

Oliver, F. W. (1887): On the Obliteration of the Sieve-tubes in the Laminariaceae. Ann. of Bot., vol. i, p. 95 .

Peirce, G. J. (1893): On the Structure of the Haustoria of some Phanerogamic Parasites. Ann. of Bot., vol. vii.

Philip, J. C. (1913) : Physical Chemistry. Its Bearing on Biology and Medicine. Arnold.

Ruhland, W. (1911): Untersuchungen über den Kohlenhydratstoffwechsel von Beta vulgaris. Jahrb. f. wiss. Bot., 1, pp. 200-57. Abstract in Bot. Centralbl., vol. cxix, 18, pp. 453-4, I9I 2.

SCHimper, A. F. W. (1885): Ueber Bildung und Wanderung der Kohlenhydrate in den Laubblättern. Bot. Zeit.

Schroeder (1911): Abstract and criticisms of Deleano's paper (1911). Zeitschr. f. Bot., pp. $768-70$.

Seward, A. C. (1902): On the so-called Phloem of Lepidodendron. New Phyt., pp. 38-46.

Strasburger, E. (1891): Histologische Beiträge. Heft III. Ueber den Bau und die Verrichtungen der Leitungsbahnen in den Pflanzen. Jena.

Sykes, M. G. (1908): The Anatomy and Histology of Macrocystis pyrifera and Laminaria saccharina. Ann. of Bot., vol. xxii.

Tansley, A. G., and Chick, E. (1901): Notes on the Conducting Tissue-system in Bryophyta. Ann. of Bot., vol. xv, pp. $1-3^{8}$.

Thoday (Sykes), M. G. (1911): On the Histological Relations between Cuscuta and its Host, Ann. of Bot., vol. xxv. 


\section{$2 \mathrm{BHL}$ Biodiversity Heritage Library}

Mangham, Sydney. 1917. "On the mechanism of translocation in plant tissues. An hypothesis, with special reference to sugar conduction in sieve-tubes." Annals of botany 31, 293-311. https://doi.org/10.1093/oxfordjournals.aob.a089647.

View This Item Online: https://www.biodiversitylibrary.org/item/232813

DOI: https://doi.org/10.1093/oxfordjournals.aob.a089647

Permalink: https://www.biodiversitylibrary.org/partpdf/320190

\section{Holding Institution}

Smithsonian Libraries

\section{Sponsored by}

Biodiversity Heritage Library

\section{Copyright \& Reuse}

Copyright Status: Not in copyright. The BHL knows of no copyright restrictions on this item.

This document was created from content at the Biodiversity Heritage Library, the world's largest open access digital library for biodiversity literature and archives. Visit BHL at https://www.biodiversitylibrary.org. 